\title{
Unhate Company of Benetton and Corporate Reputation
}

\author{
Özgül Dağlı, Üsküdar University, Turkey \\ Şeyma Esin Erben, Nişantaşı University, Turkey
}

\begin{abstract}
Organizations struggle for positive corporate reputation to affects buying behavior and brand loyalty positively. To get this result, many corporations are producing ads which look like each other: Esthetically perfect, using digital effects, showing healthy and beautiful/handsome people in spectacular places, and fate happiness shows... But Benetton did create advertisements to make people talk, to develop citizen consciousness. This study is about the Benetton's most recently lunched advertisement company named UNHATE. Researcher will discuss the ads from the corporate reputation, brand image, and from the advertisement philosophy of Benetton.
\end{abstract}

Keywords: Reputation, brand image, brand loyalty, UNHATE ads. 


\section{Introduction}

Price and quality of a product is not the only criteria for costumers for demanding a brand. Moreover there are a big variety of products that have almost the same quality and same price. So businesses have to exert significant effort to affect the customer preference for the advantage of their brands. In this context, corporations do have to look for new ways beside quality and price to differentiate themselves from their rivals. Actually they are trying to do that, but the number of successful ones is precious few. Benetton is one of the most distinguished brands in business world with its controversial publicity companies.

Benetton's last controversial "UNHATE" company won the Press Grand Prix at the Cannes Ad Festival in September 2011. This success of Benetton has taken both positive and negative reactions/criticisms from different environments. But it's obvious that Benetton has world talk on itself through these ads, and gained a good worldwide reputation.

Reputation is a matter of management, and it has grate effect on both consumer perception about the companies, and on the consumers buying preferences. Consumers tend to buy the products and services of the companies that have good reputation. Positive reputation also can create good brand image, and brand loyalty (Booker and Serenko, 2007).

In this paper the massage of the UNHATE ads will be discussed from the Benetton's understanding of advertising, and the reputation of Benetton. In the following pages it's tried first to explain the reputation concept and importance of reputation from the point of brand loyalty and consumers' buying behaviors. And then the UNHATE ads would be analyzed.

\section{Theoretical Background}

Reputation is "the opinion that people in general have about someone or something, or how much respect or admiration someone or something receives, based on past behaviour or character (http://dictionary.cambridge.org/dictionary/). According to Fombrun and Van Riel (2004), corporate reputation has six dimensions: social responsibility, emotional appeal, products and services, workplace environment, vision and leadership, and financial performance. They says that, according to the researches who works on corporate reputation perceptions, among all these dimensions, products and services, social responsibility and financial performance have the greatest effect on reputations of the companies

Consumers are no longer passive or in the dark. Because of the performance of communication and information Technologies consumers are conscious about where their money is going and who they are supporting by buying their goods. So the reputation of the enterprise or corporate reputation becomes mission-critical

\section{Reputation and Brand Image}

According to Shandwick, reputation of a company behind a brand is just as important as strong product brands. Because product brands can benefit from the overall reputation of their company. "The corporate reputation is perceived to add luster to the product brands, not just the other way around. The fusion of the corporate and product reputation has only reached its tipping point today. They are becoming nearly indivisible."

http://www.webershandwick.com/uploads/

Brand image is the "perceptions about a brand as reflected by the brand associations held in consumer memory" (Dichter, 1985; Aaker, 1991; Engel, Blackwell \& Miniard, 1995...) 


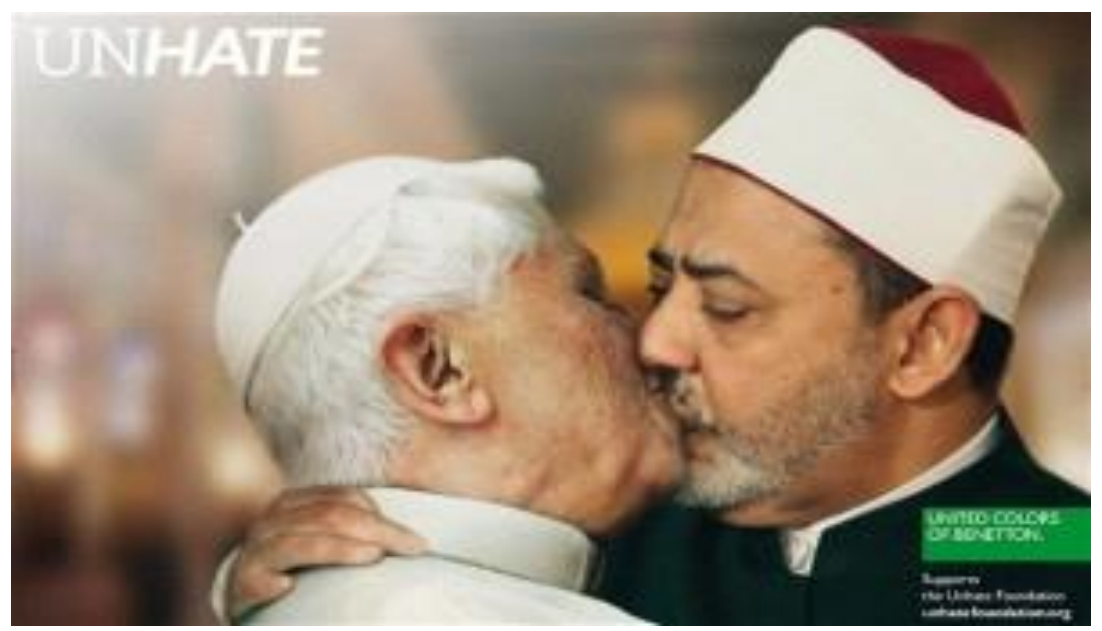

Pope and Ahmed Mohamed el-Tayeb and Imam of the Al-Azhar mosque in Cairo.

According to Aaker (1991), brand image creates not only value in a variety of ways, such as helping consumers to process information, differentiating the brand, and generating reasons to buy; but also giving positive feelings, and providing a basis for extensions. And brand associations are all the linkages that exist between a brand and the other nodes stored in memory. And consumers also want to do good as they spend.

According to the results of a research made by Shandwick on 1375 consumers (ages 18+), $\% 87$ of Chinas and $75 \%$ percent of Brazils are completely and/or mostly agree with the "More and more, I check labels to see what company is behind the product I'm buying" statement. And respectively $83 \%$ and $73 \%$ percent agree with "More and more, I try to buy products made by a company that does good things for the environment or community" statement. http://www.webershandwick.com/uploads/.

\section{UNHATE Advertising Company and Its Reflections}

As it's said above; Benetton's controversial "Unhate" ads won the Press Grand Prix at the Cannes Ad Festival in September 2011. The press jury celebrated the ads for both its universal message and ability to go beyond just the printed page. UNHATE is an integrated advertising campaign featuring print, outdoor, digital and film focusing on the kiss, the most

universal symbol of love. The ads, which are all emblazoned with the slogan "unhate," refer to the company's UNHATE Foundation, which "seeks to contribute to the creation of a new culture of tolerance, to combat hatred, building on Benetton's underpinning values"

(http://www.zap2it.com/blogs/benetton). The ad campaign features world political and religious leaders kissing each other on the mouth (http://www.redhotmarketingblender.com/). Although the meaning of this campaign was exclusively to combat the culture of hatred in all its forms; it has taken many positive and negative criticisms after it lunched. One ad in the series had featured Pope Benedict XVI kissing a Muslim imam and was pulled within hours of launch after the Vatican denounced it. Also some print publications refused the ads, including the International Herald Tribune, the Guardian and Elle Francia. However, such as The Economist, Newsweek, Le Monde's magazine in France and Germany's Fur Sie did run them.

Benetton says the accompanying press material is inviting "the leaders and citizens of the world to combat the culture of hatred". The UNHATE campain is the firsty initiatyive from a 
new Benetton foundation of the same name, launched by Alessandro Benetton, executive deputy chirman of the Benetton group. UNHATE ad company is another example of integrating the public relation, corporation reputation, and brand image successfully for the benefit of Benetton. UNHATE ads are the newest provocative and socially charged work. Benetton has realized many such shocking campaigns in the past.

\section{Benetton's' Shocking Ad Campaigns}

When photographer Olivero Toscani created for Benetton the first multiracial campaigns with the "United Colors of Benetton" slogan; Benetton moved into controversial topics such as AIDS, Gulf War casualties and so on. The philosophy behind this new understanding; was bearing itself against "life-style-advertisings" of being dull and unimaginative, creating and portraying an ideal World that does not exist. Hera are two examples from Benetton socking campaigns'. In this ad; one figure from three historically conflicting continents and all are being warmed by a single blanket. It can be seen that the women on either end of the child have their hands clasped together, and the image reminiscent of a family portrait. So this ad is much more than meets the eye.

The 1993 ad below; brought color to the AIDS pandemic. This was just over a decade after the formal recognition of the disease, when it was still charged with ideas that it was cleansing society of the undesirables.

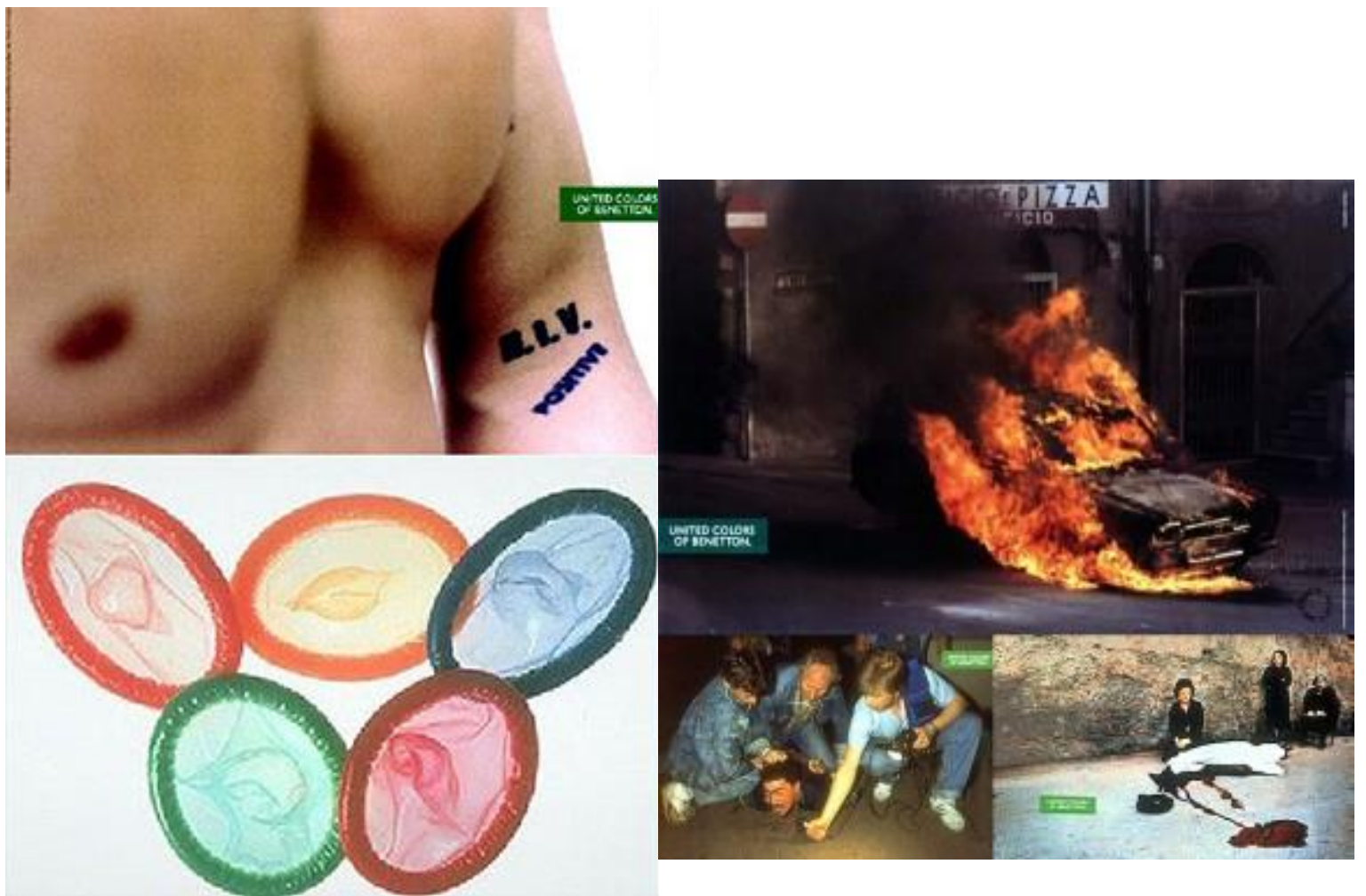

Benetton bravely uses HIV positivity to create lively, sexy images — a perspective very unlike traditional representations of AIDS as death itself.

Using iconic images from the recent news of horrors that still haunt the millions is insensitive. Very often, insensitivity is affective. The car bomb image at the top, for example, treats the issue of terrorism from an observational perspective, as if saying that the brand is 
still relevant to today's issues and that some issues cannot be considered as simply as we have seen to date.
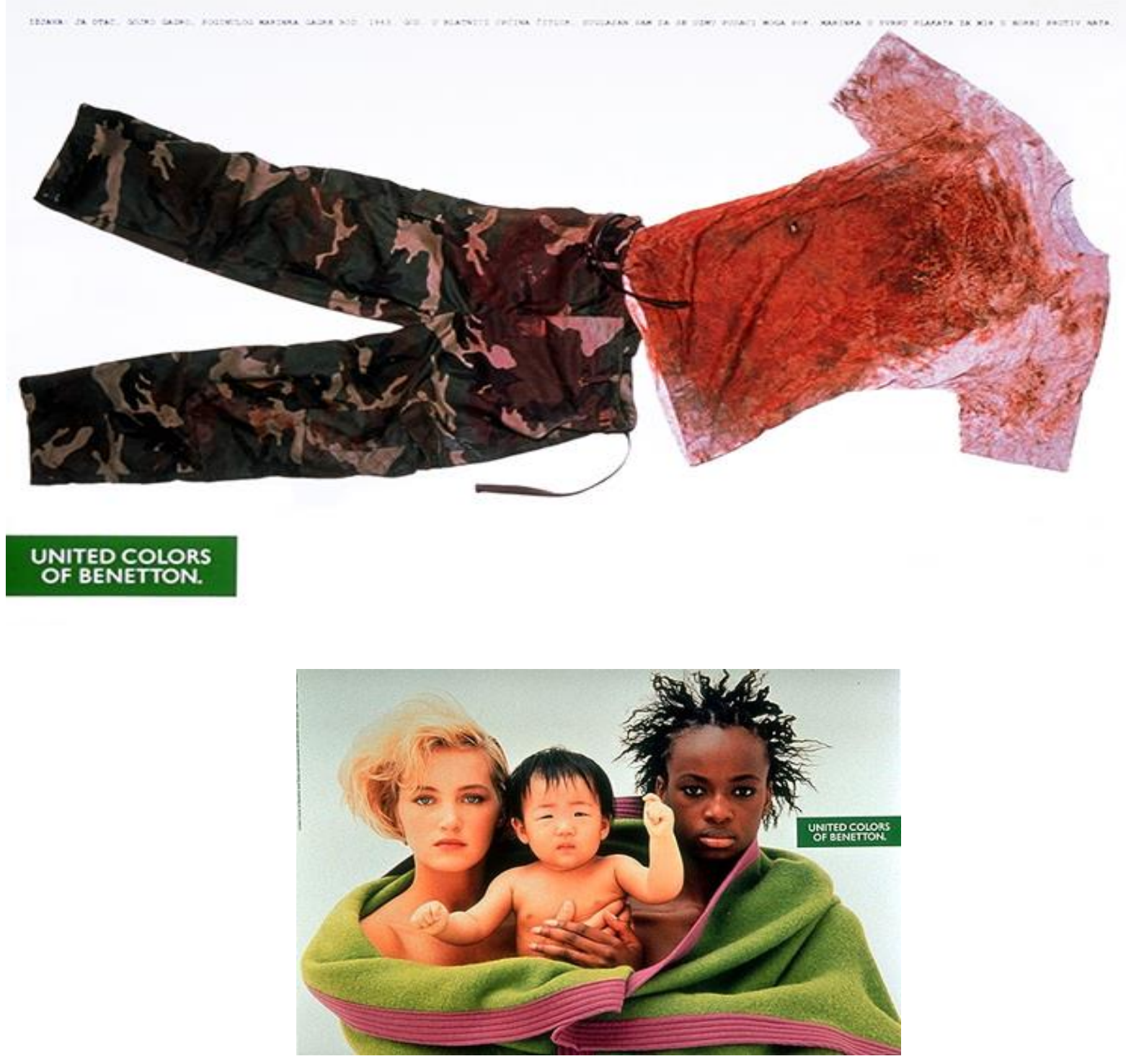

In 1994, Benetton takes the uniform of a fallen Bosnian soldier brutally wearing its red (the most uniting color of all, no?) and bullet holes. This was conveniently at the height of the war's presence in western media where it became the issue of human rights with its thousandfold complications.

\section{The Features of UNHATE Company}

The stunning (albeit photo-shopped) images of UNHATE ads push the boundaries of advertising and communication once more. Alessandro Benetton, chairman of the group, maintained that images were meant to promote the idea of "unhate" ("which is not as utopian as love") and should not be seen in the physical or sexual context. "The images are very strong, but we have to send a strong message (http://timesofindia.indiatimes.com/business/international). 


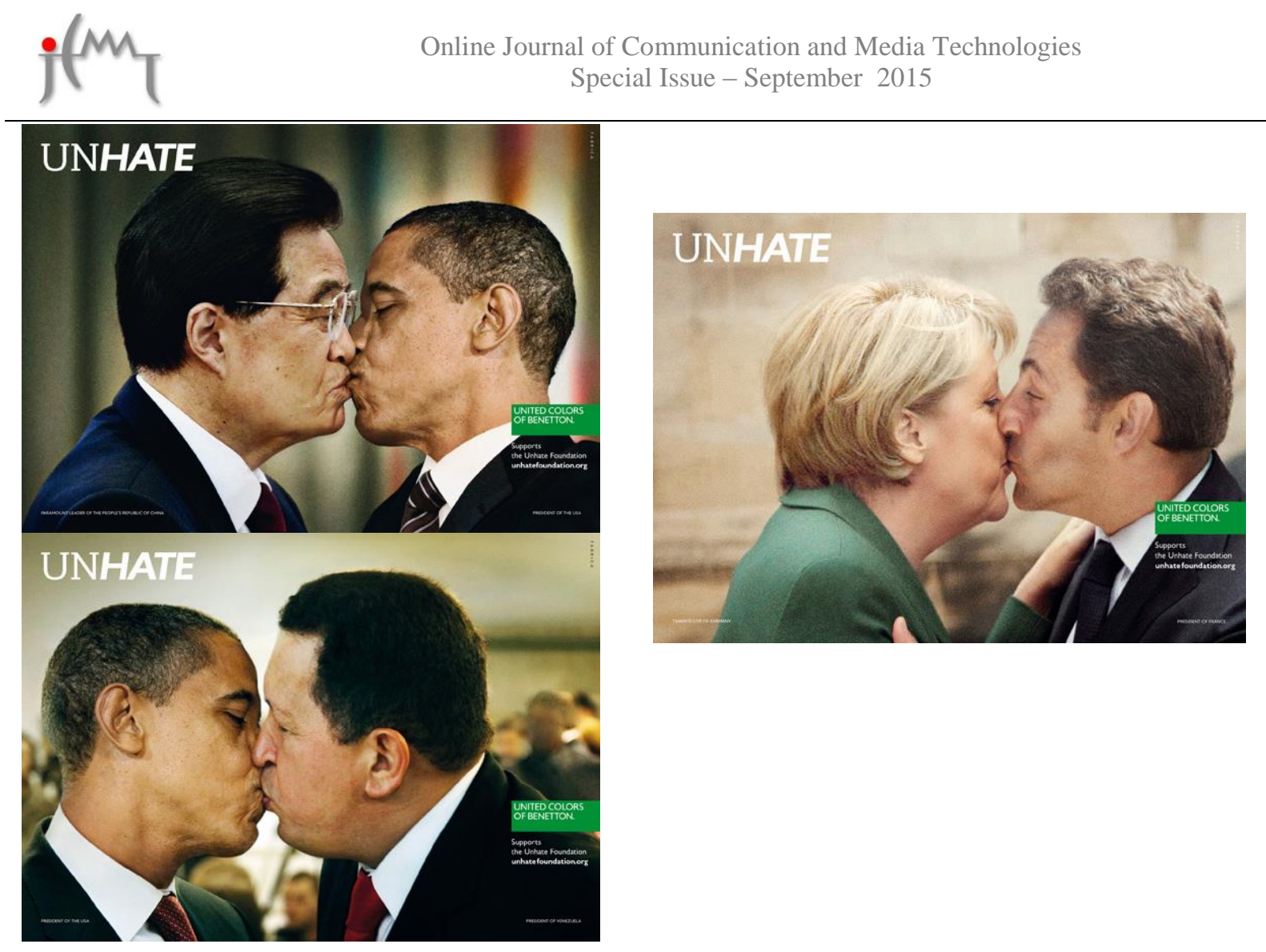

The simplicity of this gesture, a kiss, in comparison to many of the aggressive notions in the ads we have seen to date shouldn't be able to incite such strong reactions as it does.
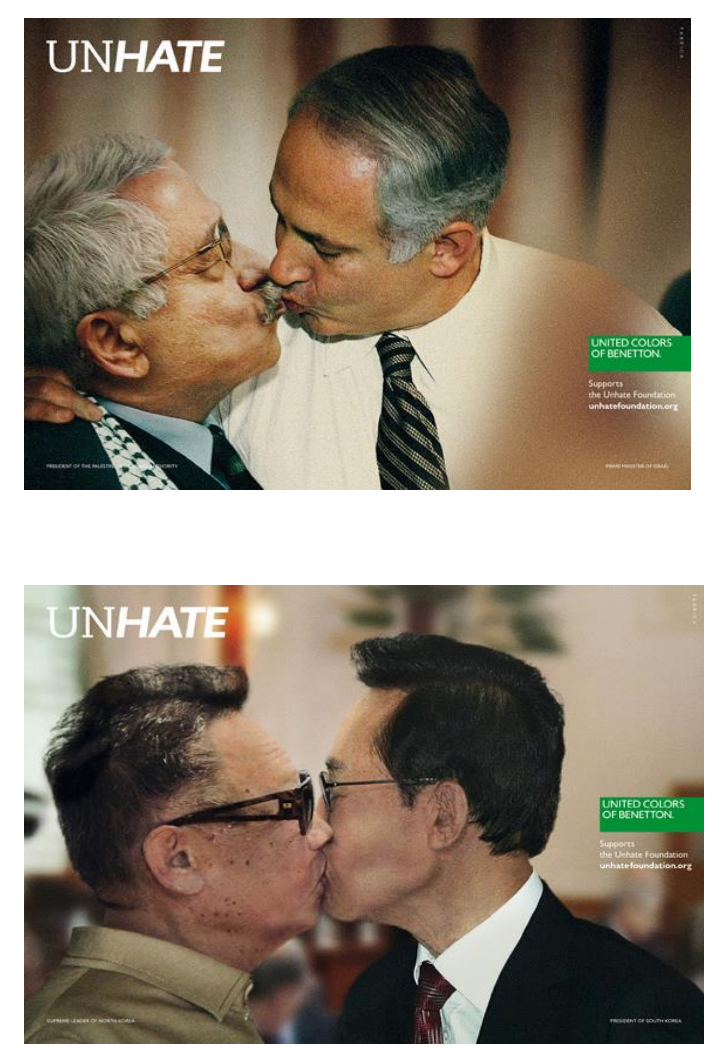

The Value of UNHATE Company 
What is wrong with these photo-shopped images? Benetton wants the world to unhate. As Benetton says "These are symbolic images of reconciliation with a touch of ironic hope and constructive provocation- to stimulate reflection on how politics, faith and ideas, even when they are divergent and mutually opposed, must still lead to dialog and mediation." http://www.creativereview.co.uk/

Brand experts said that it's possible to be controversial, protect your brand and make a serious point at the same time. "It is a risky strategy that Benetton have taken but this is a great example of a brand creating something that is a global discussion point.

Most of the Benetton advertisements are controversial touch on sensitive subjects like politics, religion, racism, etc. UNHATE ads can be seen as a new success for Benetton for combat against the hate culture.

As a public attention grab advertisement, which don't obey the rules of traditional advertisement; not making a point about the clothes. But definitely it preserve the positive feeling about the brand, and promote brand image though an eye-catching and controversial campaign. On the other hand, Benetton used media most compatible with the media, and allow everyone to participate the campaign to stimulate public being together for a global issue and around the brand. So UNHATE fits perfectly with Benetton's history of social advocacy. The company is so successful concerning the web traffic and press coverage. 500 million customers around the World visit the web site, and 600 article in 60 countries written about EN HATE ads. Ranked number 5 in the most popular subjects on Google and Twitter for one week. And this company definitely promote the brand image. It's an eye-catching and shocking advertisement. And it wouldn't be a prophecy to say that public is waiting for new advertisements, curious about the subjects that the brand could promote

\section{Last Words}

If we think of the hurtful conditions of the World, UNHATE ad company has created a very sympathetic and valuable nods in memory of human beings. There are 195 countries in the World, and there is a war in one of each three countries in the World: Exact number is 65 . http://geography.about.com/ Think of a World that $50 \%$ of its population lives on less than 2,5 dollars, and $80 \%$ lives on less than 10 dollars a day; 22.000 child die every day due to poverty. Every one child out of three lives without adequate shelter. And every one child out of three has no chance access to safe water. http://www.statisticbrain.com/world-povertystatistics/.

We all familiar with the problems mentioned above and many more. So it's part of world leaders' responsibility to lessen these unacceptable conditions. UNHATE company aimed has the leaders remember this responsibility. If the leaders able to overcome the hatred feelings against each other, and can love each other the solution will come by itself. 
Referances

Aaker, D. A. (1991), Managing Brand Equity, New York: The Free Press.

Booker, L. D, Bontis, N. and Serenko, A. (2007). The Mediating Effect of Organizational Reputation on Customer Loyalty and Service Recommendation in the Banking Industry. Management Decision. Vol.45.No. 9, 1426-1445.

Dichter, E. (1985), "What's in an Image", Journal of Consumer Marketing, 2 (1, Winter): 7581.

Engel, Blackwell, \& Miniard, (1995), Consumer Behavior. The Dryden Press, Harcourt Brace

College Publishers.

Fombrun, C and Van Riel, C. B.M. (2004). Fame and Fortune: How Sucessful Companies Build Winning Reputations, Pearson Inc.

Nakra, P. (2000). Corporate Reputation Management: “CRM”with a Strategic Twist?, Public Relations Quarterly.

\section{Internet Resources}

(http://dictionary.cambridge.org/dictionary/). 10.12. 2014

(http://geography.about.com/cs/countries/a/numbercountries.htm). 2.28.2015

Sandwick, W. The Company Behind the bran).

(http://timesofindia.indiatimes.com/business/international). 3.3.2015

(http://www.redhotmarketingblender.com/). 3.3.2015

(http://www.zap2it.com/blogs/benetton). 20.03.2015

(http://www.creativereview.co.uk/). 5.3.2015 